\title{
OBOWIĄZEK UDOSTĘPNIENIA INFORMACJI PUBLICZNEJ PRZEZ KOŚCIELNE OSOBY PRAWNE W ZWIAZZKU Z PROWADZENIEM CMENTARZY WYZNANIOWYCH. GLOSA DO WYROKU NACZELNEGO SĄDU ADMINISTRACYJNEGO Z DNIA 4 GRUDNIA 2020 R. (I OSK 125/19)
}

The obligation of church legal entities to disclose public information in connection with the running of religious cemeteries: A commentary to the judgment of the Supreme Administrative Court of December 4, 2020 (I OSK 125/19)

Streszczenie: Przedmiotem niniejszego opracowania jest analiza wyroku Naczelnego Sądu Administracyjnego z dnia 4 grudnia 2020 r. (I OSK 125/19). Glosowane orzeczenie jest jednym z serii wydanych przez sądy administracyjne w związku z aktywnością organizacji „Sieć Obywatelska - Watchdog”, która w maju 2018 r. zwróciła się z wnioskami do ponad 30 wybranych parafii w Polsce o udostępnienie informacji publicznej. Głównym celem tego działania było poznanie cennika usług cmentarnych, kwoty środków uzyskanych z opłat, jak również liczby pochowanych osób. Orzecznictwo dotyczące rzeczonych wniosków jest zróżnicowane. Niektóre z prezentowanych w nim tez zostały omówione w przeprowadzonej analizie, co pozwoliło szerzej spojrzeć na problematykę prowadzenia cmentarzy przez kościelne osoby prawne. W artykule dokonano oceny obowiązków parafii rzymskokatolickich jako podmiotów prowadzących cmentarze w omawianym zakresie. Autor wypowiada pogląd, że obowiązek udostępniania informacji publicznej dotyczy jedynie tych sytuacji, w których - wobec braku cmentarza komunalnego - na cmentarzu katolickim pochowane są osoby, które nie identyfikowały się z Kościołem Katolickim.

* Dr hab., prof. ASzWoj, Katedra Prawa Publicznego i Prywatnego, Instytut Prawa, Akademia Sztuki Wojennej, Al. gen. Antoniego Chruściela 103, 00-910 Warszawa, e-mail: ma.bielecki@akademia.mil.pl. ORCID 0000-0003-3880-017X. 
Słowa kluczowe: dostęp do informacji publicznej; cmentarze wyznaniowe; cmentarze komunalne

Abstract: The present paper outlines the analysis of the judgment of the Supreme Administrative Court of December 4, 2020 (I OSK 125/19). The commented judgment is one of the series of judgments passed by administrative courts in connection with the activity of the organization „Sieć Obywatelska - Watchdog”, which in May 2018 formally requested access to public information from over 30 selected parishes in Poland. The main purpose of the requests was to obtain information on the fees and charges related to cemetery services, the amount of money earned as well as the number of buried individuals. The case law pertaining to the requests has been varied. Some of the claims made by the courts are discussed in this paper, which hopefully contributes to a broader understanding of the complexity of issues connected with running cemeteries by church legal entities. In conclusion, the author provides an assessment of the relevant responsibilities of Roman Catholic parishes as entities running religious cemeteries. He takes the view that the obligation to disclose public information applies only to cases where, in the absence of a communal cemetery, people who did not identify with the Catholic Church are buried at a Catholic cemetery.

Key words: access to public information; religious cemeteries; municipal cemeteries

\section{WPROWADZENIE}

Glosowane orzeczenie jest konsekwencją złożenia skargi kasacyjnej $\mathrm{w}$ jednej $\mathrm{z}$ wielu spraw rozpatrywanych przez sądy administracyjne w związku z aktywnością organizacji „Sieć Obywatelska - Watchdog”, która w maju 2018 r. zwróciła się z wnioskami do ponad 30 wybranych parafii w Polsce o udostępnienie informacji publicznej ${ }^{1}$. Głównym celem tego działania było poznanie cennika usług cmentarnych, kwoty środków uzyskanych z opłat, jak również liczby pochowanych osób ${ }^{2}$. Linia orzecznicza zaprezentowana w judykatach będących pokłosiem rzeczonych

1 Skarga dotyczy wyroku Wojewódzkiego Sądu Administracyjnego w Gdańsku z dnia 6 września 2018 r., II SAB/Kr 113/18, LEX nr 2562431.

2 P. Kłucińska, Grobowa cisza, https://siecobywatelska.pl/grobowa-cisza/ [dostęp: 23.02.2021]. 
wniosków jest zróżnicowana ${ }^{3}$. Niektóre z jej elementów zostaną zasygnalizowane w prowadzonej analizie, co pozwoli szerzej spojrzeć na problematykę prowadzenia cmentarzy wyznaniowych przez kościelne osoby prawne.

Głównym zagadnieniem, które zostało podniesione przez wnioskodawcę, był obowiązek udostępnienia informacji publicznej przez parafie rzymskokatolickie ze względu na rodzaj prowadzonej aktywności. Niemniej jednak sądy administracyjne niejako ,przy okazji” odnosiły się do innych istotnych kwestii z obszaru relacji państwo-Kościół, na co również należy zwrócić uwagę.

Rozpatrywana kwestia jest bezpośrednią konsekwencją prowadzenia przez parafie rzymskokatolickie cmentarzy, na których istnieje możliwość pochówku osób należących do innych wyznań bądź deklarujących się jako niewierzący.

Do XVIII w. w Polsce funkcjonowały wyłącznie cmentarze wyznaniowe. Dopiero przy końcu tegoż stulecia zaczęto na obrzeżach miast zakładać cmentarze komunalne ${ }^{4}$. Jednakże same cmentarze świeckie pojawiły się już pod koniec XVII w., na wydzielonych terenach podmiejskich. Miejsca te mogły być własnością Skarbu Państwa bądź stanowić mienie komunalne. Obecnie obowiązująca ustawa z dnia 31 stycznia 1959 r. o cmentarzach i chowaniu zmarłych ${ }^{5}$ wyodrębnia wyłącznie cmentarze komunalne i wyznaniowe (art. 1 i 2). Wśród cmentarzy świeckich można wyróżnić cmentarze: komunalne, wojenne i specjalne (groby osób szczególnie zasłużonych usytuowane $\mathrm{z}$ dala od cmentarzy) ${ }^{6}$.

Przepisy prawne w zakresie udostępniania cmentarzy przez katolickie osoby prawne przeszły ewolucję i obecnie występują pewne różnice

3 Zob. $\mathrm{m}$ in.: wyrok Wojewódzkiego Sądu Administracyjnego w Lublinie z dnia 10 października 2019 r., II SAB/Lu 57/19, LEX nr 2759123; wyrok Wojewódzkiego Sądu Administracyjnego w Gdańsku z dnia 23 października 2018 r., II SAB/Gd 70/18, LEX nr 2574129; wyrok Wojewódzkiego Sądu Administracyjnego w Poznaniu z dnia 5 grudnia 2018 r., IV SAB/Po 118/18, LEX nr 2734670; wyrok Wojewódzkiego Sądu Administracyjnego w Białymstoku z dnia 25 października 2018 r., II SAB/Bk 90/18, LEX nr 2579322.

4 Hodor 2012, 282.

5 Ustawa z dnia 31 stycznia 1959 r. o cmentarzach i chowaniu zmarłych, tekst jedn. Dz. U. z 2020 r., poz. 1947, dalej: u.o.c.

6 Dziobek-Romański 1999, 11. 
w porównaniu ze stanem prawnym obowiązującym w okresie II RP. Zgodnie z art. XVII Konkordatu z 1925 r. ${ }^{7}$ „osoby prawne kościelne i zakonne miały prawo zakładania, posiadania i zarządzania, według prawa kanonicznego i zgodnie z powszechnem prawem państwowem, cmentarzy, przeznaczonych do grzebania katolików”. A zatem umowa ze Stolicą Apostolską nie przewidywała ani możliwości, ani obowiązku udostępniania miejsca na prowadzonych przez Kościół nekropoliach dla przedstawicieli innych wyznań i bezwyznaniowców. Problematykę tę uregulowano dopiero w ustawie z 1932 r. o chowaniu zmarłych i stwierdzaniu przyczyn zgonu. ${ }^{8}$ W świetle proklamowanych wówczas norm, zasadą był pochówek na cmentarzu gminnym w obrębie gminy miejsca zgonu. Na cmentarzach innych osób prawnych grzebanie zwłok mogło dokonywać się jedynie za zgodą zarządcy cmentarza z zastrzeżeniem art. 15 ust. 1 (art. 8 ust. 1). Przewidziany wyjątek dotyczył sytuacji przyjmowania przez związki wyznaniowe zwłok osób nienależących do danej konfesji, jeżeli w promieniu $30 \mathrm{~km}$ od miejsca zgonu nie było cmentarza gminnego lub odpowiedniego cmentarza wyznaniowego, bądź też cmentarza opuszczonego, uznanego przez właściwą powiatową władzę administracji ogólnej za nadający się do grzebania zwłok.

W momencie wejścia w życie u.o.c. (tj. 16 lutego 1959 r.) w miejscowościach, w których nie było cmentarzy komunalnych, zarządy cmentarzy wyznaniowych do czasu ich założenia powinny były przyjmować na cmentarzach przez siebie prowadzonych zwłoki osób zmarłych bezwyznaniowych lub należących do wyznania, którego nie było w danej miejscowości ${ }^{9}$. Treść powyższej normy dwukrotnie ulegała zmianom ${ }^{10}$, by ostatecznie przyjąć następujące brzmienie: „W miejscowościach, w których nie ma cmentarzy komunalnych, zarząd cmentarza wyznaniowego

7 Konkordat zawarty pomiędzy Stolicą Apostolską a Rzecząpospolitą Polską w dniu 10 lutego 1925 r., Dz. U. z 1925 r. Nr 72, poz. 501.

8 Ustawa z dnia 17 marca 1932 r. o chowaniu zmarłych i stwierdzaniu przyczyny zgonu, Dz. U. z 1932 r. Nr 35, poz. 359.

9 Wersja ogłoszona w: Dz. U. z 1959 r. Nr 11, poz. 62.

10 Art. 74 ust. 4 ustawy z dnia 17 maja 1989 r. o stosunku Państwa do Kościoła Katolickiego w Rzeczypospolitej Polskiej, Dz. U. z 1989 r. Nr 29, poz. 154 - tekst ogłoszony, dalej: u.s.p.K.K.; art. 1 ustawy z dnia 26 czerwca 1997 r. o zmianie ustawy o cmentarzach i chowaniu zmarłych, Dz. U. z 1997 r. Nr 126, poz. 805. 
jest obowiązany umożliwić pochowanie na tym cmentarzu, bez jakiejkolwiek dyskryminacji, osób zmarłych innego wyznania lub niewierzących" (art. 8 ust. 2).

Uchwalona w 1989 r. ustawa o stosunku Państwa do Kościoła Katolickiego w RP w art. 45 ust. 3 również stanowiła, że w miejscowościach, gdzie nie było cmentarzy komunalnych, zarządy cmentarzy umożliwiają pochowanie na równych prawach także innych zmarłych. Niniejsza norma, bez zmian, zachowuje swoją aktualność do dzisiaj ${ }^{11}$. Pewne wątpliwości w interesujących nas kwestiach pojawiły się w związku z brzmieniem art. 8 ust. 3 Konkordatu z 1993 r., który stanowił, że: „Miejscom przeznaczonym przez właściwą władzę kościelną do sprawowania kultu i grzebania zmarłych Państwo gwarantuje w tym celu nienaruszalność"12.

Strona państwowa uznała bowiem, że dookreślenia wymaga pojęcie nienaruszalności, które zgodnie ze złożoną deklaracją nie mogło być rozumiane jako prawo odmowy pochowania na cmentarzu katolickim osoby innego wyznania lub niewierzącej ${ }^{13}$. Na dzień wydawania glosowanego orzeczenia, zarządcy cmentarzy wyznaniowych zostali zobowiązani do umożliwienia pochowania na tym cmentarzu, bez jakiejkolwiek dyskryminacji, osób zmarłych innego wyznania lub niewierzących. Użyte zaś przez prawodawcę kryterium „dyskryminacji” koresponduje z konstytucyjnym zakazem proklamowanym w art. 32 ust. 2 Ustawy zasadniczej ${ }^{14}$. Zróżnicowanie statusu określonego podmiotu może przybrać postać ,dyskryminacji bezpośredniej” bądź „dyskryminacji pośredniej”. „Dyskryminacja bezpośrednia" oparta jest na niedozwolonych i oczywistych kryteriach

11 Ustawa z dnia 17 maja 1989 r. o stosunku Państwa do Kościoła Katolickiego w Rzeczypospolitej Polskiej, tekst jedn. Dz. U. z 2019 r., poz. 1347 z późn. zm.

12 Konkordat między Stolicą Apostolską a Rzecząpospolitą Polską podpisany dnia 28 lipca 1993 r., Dz. U. z 1998 r. Nr 51, poz. 318.

13 Oświadczenie Rządowe z dnia 26 stycznia 1998 r. w sprawie Deklaracji Rządu Rzeczypospolitej Polskiej z dnia 15 kwietnia 1997 r. w celu zapewnienia jasnej wykładni przepisów Konkordatu między Stolicą Apostolską a Rzecząpospolitą Polską, podpisanego w Warszawie w dniu 28 lipca 1993 r., M.P. z 1998 r. Nr 4, poz. 51.

14 „Nikt nie może być dyskryminowany w życiu politycznym, społecznym lub gospodarczym z jakiejkolwiek przyczyny”. Konstytucja Rzeczypospolitej Polskiej z dnia 2 kwietnia 1997 r., Dz. U. z 1997 r. Nr 78, poz. 483 z późn. zm. Szerzej na temat ochrony godności osoby zmarłej zob. Marczak 2015, 596-609. 
różnicujących. Z kolei „dyskryminacja pośrednia” występuje w sytuacji, gdy pozornie neutralne kryterium różnicujące prowadzi do niedopuszczalnego zróżnicowania podmiotów ${ }^{15}$.

\section{STAN FAKTYCZNY SPRAWY}

Z uwagi na przedmiot badanej sprawy, w niniejszej glosie ocenie zostaną poddane w głównej mierze te fakty i tezy orzeczenia, które związane są $\mathrm{z}$ zagadnieniem prowadzenia cmentarzy wyznaniowych przez kościelne osoby prawne.

W dniu 15 maja 2018 r. stowarzyszenie „Sieć Obywatelska Watchdog" ${ }^{\prime 16}$, powołując się na dyspozycję zawartą w art. 8 ust. 2 u.o.c. zwróciło się do proboszcza jednej z parafii o udostępnienie informacji publicznej. W złożonym wniosku sformułowano żądania co do wskazania: 1) liczby osób pochowanych na cmentarzu w 2017 r.; 2) rodzaju pobieranych opłat w 2017 r.; 3) istnienia cennika wysokości wnoszonych opłat; 4) kwoty uzyskanych środków z opłat cmentarnych za $2017 \mathrm{r}$.

$\mathrm{Z}$ racji braku odpowiedzi na ww. wniosek, w dniu 2 lipca 2018 r. stowarzyszenie wniosło do Wojewódzkiego Sądu Administracyjnego w Krakowie skargę na bezczynność proboszcza, w zakresie „rozpatrzenia wniosku o udostępnienie informacji publicznej”. W sformułowanych zarzutach podniesiono fakt naruszenia przez ,zobowiązany podmiot” art. 61 Konstytucji $\mathrm{RP}^{17}$ W zw. $\mathrm{z}$ art. 13 ust. 1 ustawy z dnia 6 września 2001 r. o dostępie

15 Zob. m.in. wyrok Trybunału Konstytucyjnego z dnia 5 lipca 2011 r., P14/10, OTK-A 2011, Nr 6, poz. 49.

16 Dalej: stowarzyszenie.

17 Art. 61 ust. 1 stanowi: „Obywatel ma prawo do uzyskiwania informacji o działalności organów władzy publicznej oraz osób pełniących funkcje publiczne. Prawo to obejmuje również uzyskiwanie informacji o działalności organów samorządu gospodarczego i zawodowego, a także innych osób oraz jednostek organizacyjnych w zakresie, w jakim wykonują one zadania władzy publicznej i gospodarują mieniem komunalnym lub majątkiem Skarbu Państwa”. Ust. 2 stanowi zaś: „Prawo do uzyskiwania informacji obejmuje dostęp do dokumentów oraz wstęp na posiedzenia kolegialnych organów władzy publicznej pochodzących z powszechnych wyborów, z możliwością rejestracji dźwięku lub obrazu”. 
do informacji publicznej ${ }^{18}$. Rzeczone naruszenie miało polegać na braku „realizacji wniosku $\mathrm{w}$ terminie ustawowym, pomimo spełnienia zakresu podmiotowego i przedmiotowego ustawy o dostępie do informacji publicznej".

Jak podnosił skarżący, do wytypowania powyższej parafii przez stowarzyszenie przyczynił się brak cmentarza komunalnego na jej terenie. To zaś, zdaniem stowarzyszenia, spowodowało, że cmentarz parafialny przejął funkcję cmentarza komunalnego. W związku z tym parafia wykonuje zadania, które jak podniesiono we wniosku: „dotyczą bezpośrednio władzy publicznej", co obliguje proboszcza do udostępnienia informacji publicznej w zakresie objętym wnioskiem. W odpowiedzi na skargę proboszcz wniósł o jej oddalenie oraz zasądzenie od skarżącego kosztów postępowania, w tym kosztów zastępstwa procesowego.

W wyroku z dnia 6 września 2018 r. (II SAB/Kr 113/13) WSA w Krakowie uznał, że proboszcz pozostaje w bezczynności w związku ze złożonym wnioskiem, co spowodowało, że został zobowiązany w terminie 14 dni do wydania aktu lub dokonania czynności załatwienia wniosku. W związku z okolicznościami sprawy uznano, że bezczynność ta nie miała miejsca $\mathrm{z}$ rażącym naruszeniem prawa.

W złożonej skardze kasacyjnej proboszcz zaskarżył w całości powyższe orzeczenie. Zrzekł się ponadto rozprawy, wnosząc o uchylenie w całości zaskarżonego wyroku oraz przekazanie sprawy do ponownego rozpoznania WSA w Krakowie, ewentualnie o uchylenie zaskarżonego wyroku i rozpoznanie skargi poprzez jej oddalenie.

\section{ROZSTRZYGNIĘCIE SPRAWY I JEGO OCENA}

Naczelny Sąd Administracyjny w dniu 4 grudnia 2020 r., na posiedzeniu niejawnym Izby Ogólnoadministracyjnej, postanowił oddalić skargę i za-

18 Ustawa z dnia 6 września 2001 r. o dostępie do informacji publicznej, tekst jedn. Dz. U. z 2020 r., poz. 2176 z późn. zm., dalej: u.d.i.p. Zob. też art. 13 ust. 1 u.d.i.p., który stanowi „Udostępnianie informacji publicznej na wniosek następuje bez zbędnej zwłoki, nie później jednak niż w terminie 14 dni od dnia złożenia wniosku, z zastrzeżeniem ust. 2 i art. 15 ust. 2". 
sądzić od proboszcza na rzecz stowarzyszenia zwrot kosztów postępowania kasacyjnego.

W pierwszej kolejności NSA zwrócił uwagę na uchybienia w tekście skargi kasacyjnej. Szersza analiza tychże rozważań zostanie pominięta ze względu na przewodni temat opracowania. Należy jednakże zauważyć, że pomimo uznania przez NSA nieskuteczności postawionego zarzutu, w wyroku znalazło się odniesienie dotyczące kwestii doręczenia wniosku wysłanego na adres poczty elektronicznej. Powołując się na pogląd utrwalony w orzecznictwie, NSA podkreślił, że wynika z niego w istocie domniemanie, iż ,jeżeli wiadomość została prawidłowo nadana na oficjalny adres poczty elektronicznej organu, to znaczy, że dotarła ona do adresata. Odmienne zapatrywanie sprawiałoby bowiem, że w praktyce prawo do wnioskowania o informację publiczną za pomocą poczty elektronicznej (e-mail) byłoby iluzoryczne, a jego skuteczność zależna byłaby od arbitralnej woli organu" ${ }^{\prime 19}$. Należy zaakceptować powyższą opinię. Zgodnie bowiem z treścią art. 10 ust. 1 u.d.i.p. „,informacja publiczna, która nie została udostępniona w Biuletynie Informacji Publicznej lub centralnym repozytorium jest udostępniana na wniosek". Przywołana dyspozycja nie wymaga, żeby złożony wniosek miał określoną formę. Zarówno w doktrynie, jak i orzecznictwie, panuje zgodny pogląd, że wniosek ten może mieć dowolną postać, o ile wynika z niego w sposób jasny co jest jego przedmiotem $^{20}$. Nie ma żadnych przeszkód normatywnych, żeby wniosek złożony był w formie elektronicznej, zwykłą pocztą elektroniczną, bez konieczności używania kwalifikowanego podpisu elektronicznego czy profilu zaufanego ${ }^{21}$.

W dalszej kolejności NSA odniósł się do stanowiska wyrażonego w skardze kasacyjnej, zgodnie z którym z wykładni dyspozycji zawartych w: art. 1 ust. 1, art. 3 ust. 1 pkt 1 i ust. 2, art. 4 ust. 1 pkt 5 u.d.i.p. w zw. z art. 8 ust. 2 u.o.c., art. 15 oraz art. 45 ust. 1, 3 i 4 u.s.p.K.K. oraz art. 8 ust. 2 Konkordatu wynika, że WSA wyciągnął błędne wnioski. W zaskarżonym

19 Naczelny Sąd Administracyjny powołuje się na postanowienie NSA z dnia 18 listopada 2015 r., I OSK 2897/15, LEX nr 1989918.

20 Wyrok Wojewódzkiego Sądu Administracyjnego w Lublinie z dnia 6 maja 2014 r., II SAB/Lu 11/14, LEX nr 1531625. Zob. Kamińska, Rozbicka-Ostrowska 2016.

${ }^{21}$ Zob. Aleksandrowicz 2008; wyrok Wojewódzkiego Sądu Administracyjnego w Gdańsku z dnia 23 października 2018 r., II SAB/Gd 70/18. 
wyroku uznano bowiem, że parafia jest podmiotem, któremu powierzono wykonanie zadania publicznego w oparciu o art. 8 ust. 2 u.o.c., a tym samym proboszcz ma obowiązek udzielić informacji w tym zakresie. Ponadto strona skarżąca uznała, że w kategoriach zadania publicznego nie mieści się obowiązek dokonania pochówku osób innej wiary. Jak podniesiono w skardze kasacyjnej, z dyspozycji zawartej w art. 8 ust. 2 u.o.c. wynika wyłącznie to, że zarząd cmentarza wyznaniowego ma jedynie obowiązek polegający na umożliwieniu pochowania na prowadzonym przez siebie cmentarzu bez jakiejkolwiek dyskryminacji osób zmarłych innego wyznania lub niewierzących. A zatem jak słusznie zauważa NSA, istota zarzutu sprowadza się do odpowiedzi na pytanie, czy obowiązek umożliwienia realizacji prawa do godnego pochówku wchodzi w zakres zadań publicznych.

W dalszej części uzasadnienia NSA dokonuje wykładni pojęcia zadania publicznego. $\mathrm{Z}$ punktu widzenia podejmowanej tematyki istotne są następujące ustalenia. Po pierwsze, aby mówić o ciążącym na danym podmiocie obowiązku realizacji zadania publicznego, konieczne jest nałożenie na ten podmiot obowiązku wykonania danego zadania lub obowiązku osiągnięcia wyznaczonego celu. Po drugie, zadania publiczne są związane z sytuacją prawną obywateli. Dlatego też - jak zauważa NSA - przyjmuje się, że istnienie określonego zadania umożliwia obywatelowi domaganie się jego wykonania. Po trzecie, do zakwalifikowania danej powinności jako kategorii zadania publicznego nie jest konieczne, aby na jego realizację wyodrębniono środki publiczne.

W odróżnieniu od WSA w Krakowie, który zakwalifikował prowadzenie cmentarza wyznaniowego przez parafię jako zadanie publiczne, NSA nie podzielił tej opinii. Stwierdził natomiast, że w kategorii tej mieści się realizowanie na takich cmentarzach publicznego prawa podmiotowego do godnego pochówku. Powyższa kwalifikacja, zdaniem NSA, wypływa z zasady ochrony godności osoby ludzkiej zarówno za jej życia, jak i po śmierci. Opierając się na ustaleniach zaprezentowanych w literaturze przedmiotu, NSA słusznie zauważył, że na rzeczone uprawnienie składają się dwa elementy. Pierwszy z nich ma charakter obligatoryjny i bezwzględnie obowiązujący w czasie i dotyczy pochowania zgodnego ze standardami prawnymi i zwyczajowymi. Drugi z elementów ma zaś charakter obligatoryjny i względnie obowiązujący w czasie i dotyczy 
zapewnienia miejsca pochówku nieuwłaczającego godności i pamięci osoby zmarłej ${ }^{22}$. Należy zgodzić się ze stanowiskiem NSA, że prowadzenie cmentarza wyznaniowego nie jest zadaniem publicznym, obciążającym parafię, natomiast w kategorii tej mieści się obowiązek umożliwienia godnego pochówku niezależnie od tego, czy osoba zmarła należała do Kościoła Katolickiego. Na poparcie powinności parafii NSA powołuje się na brzmienie art. 45 ust. 3 u.s.p.K.K., gdzie w stosunku do zarządów cmentarzy wyznaniowych prawodawca używa zwrotu „umożliwiają”, a nie „mogą umożliwiać”. Zdaniem NSA w rozpatrywanej sprawie nie mamy do czynienia z przeniesieniem zadania publicznego z gminy na parafię, co stwierdził WSA w Krakowie. Jeżeli prowadzenie cmentarza wyznaniowego byłoby ukierunkowane na realizowanie zadań publicznych, wówczas należałoby przyjąć obowiązek ich tworzenia i utrzymywania, co nie znajduje podstaw prawnych.

NSA nie zanegował również słusznej opinii WSA w Krakowie, który dokonując wykładni obowiązujących przepisów zauważył, że zakładanie i rozszerzanie cmentarzy komunalnych, a także ich prowadzenie, należy do zadań własnych gminy. Wynika to wprost z art. 1 ust. 1 u.o.c. oraz z art. 7 ust. 1 pkt 13 ustawy o samorządzie gminnym ${ }^{23}$. Natomiast o założeniu lub rozszerzeniu cmentarza wyznaniowego, a także o zamknięciu cmentarza wyznaniowego decyduje właściwa władza kościelna, po zasięgnięciu opinii właściwego inspektora sanitarnego, przy czym może to odbywać się wyłącznie na terenie przeznaczonym na ten cel w miejscowym planie zagospodarowania przestrzennego (art. 1 ust. 3 u.o.c.). Ponadto zgodnie $\mathrm{z}$ art. 2 u.o.c. utrzymanie cmentarzy komunalnych i zarządzanie nimi należy do właściwych wójtów (burmistrzów, prezydentów miast), na których terenie cmentarz jest położony (ust. 1), natomiast utrzymanie cmentarzy wyznaniowych i zarządzanie nimi należy do związków wyznaniowych (ust. 2). Następuje więc wyraźne rozgraniczenie kompetencji pomiędzy władzą kościelną i samorządową, które w sposób całkowicie niezależny od siebie zajmują się administrowaniem cmentarzy.

22 Dobosz 2017, 808-809.

23 Ustawa z dnia 8 marca 1990 r. o samorządzie gminnym, tekst jedn. Dz. U. z 2020 r., poz. 1378 . 
Warto zauważyć, że w podobnym duchu jak NSA wyraził się także WSA w Białymstoku, rozpatrując wniosek stowarzyszenia skierowany do innej z parafii ${ }^{24}$. W wydanym wyroku WSA stwierdził bowiem, że ,[...] wskazane powyżej przepisy ukierunkowują sposób interpretacji użytego w art. 8 ust. 2 ustawy o cmentarzach «obowiązku umożliwienia pochówku» nie jako obowiązku bezwarunkowego, ale respektującego nienaruszalność miejsca kultu religijnego. Dlatego też w ustawie o cmentarzach wprowadzono «obowiązek umożliwienia pochówku», a nie bezwzględny «obowiązek pochowania». Ze wskazanych wyżej powodów nie można również w sposób automatyczny przyjąć, że z braku w miejscowości cmentarza komunalnego, cmentarz parafialny przejmuje rolę cmentarza komunalnego".

W konsekwencji WSA w Białymstoku doprecyzował charakter obowiązku ciążącego na proboszczu, który reprezentując parafię wykonuje zadania publiczne w zakresie umożliwienia pochowania na cmentarzu wyznaniowym osób innego wyznania bez ich dyskryminacji, gdy w miejscowości nie ma cmentarza komunalnego i to zadanie dotyczy osób zmarłych innego wyznania lub niewierzących i tylko w tym zakresie jest on zobowiązany do udostępnienia informacji publicznej.

Naczelny Sąd Administracyjny krytycznie odniósł się również do zarzutu podniesionego w skardze kasacyjnej, dotyczącego tego, że proboszcz nie ma obowiązku gromadzenia i przechowywania informacji w zakresie wypełnienia dyspozycji określonej w art. 8 ust. 2 u.o.c. NSA broniąc stanowiska wyrażonego przez WSA stwierdził, że jego rozstrzygnięcie „dotyczyło wyłącznie stwierdzenia bezczynności proboszcza na skutek złożonego wniosku o dostęp do informacji publicznej, a więc wskazywało na konieczność jego załatwienia zgodnie z przepisami u.d.i.p. Sąd nie zawarł rozstrzygnięcia obligującego proboszcza do udostępnienia informacji, której proboszcz nie posiada". A zatem ani WSA, ani NSA nie rozstrzygał problemu, w jakim zakresie winny zostać udostępnione informacje, będące w posiadaniu zarządu cmentarza wyznaniowego. W wydanych judykatach uznano jedynie, że proboszcz dysponuje informacjami publicznymi i jest zobowiązany do ich udostępnienia. Należy pozytywnie odnieść się do powyższego stanowiska i zaakceptować wniosek oparty zarówno

24 Wyrok Wojewódzkiego Sądu Administracyjnego w Białymstoku z dnia 25 października 2018 r., II SAB/Bk 90/18, LEX nr 2579322. 
na przepisach u.d.i.p., jak i orzecznictwie NSA, który został zaprezentowany w wyroku WSA w Krakowie. Zgodnie z jego treścią „za informację publiczną uznaje się wszelkie informacje wytworzone przez władze publiczne oraz osoby pełniące funkcje publiczne, a także inne podmioty, które wykonują funkcje publiczne lub gospodarują mieniem publicznym (komunalnym bądź Skarbu Państwa), jak również informacje odnoszące się do wspomnianych władz, osób i innych podmiotów, niezależnie od tego, przez kogo zostały wytworzone". Oznacza to, że nie ma przeszkód, aby działający w imieniu parafii proboszczowie zobowiązani zostali do udostępnienia informacji publicznych, jeżeli spełniają któryś z powyższych warunków. W rozpatrywanej sprawie mamy do czynienia z wykonywaniem funkcji publicznych. Ponadto obowiązek udostępnienia informacji publicznej przez proboszcza nie budzi wątpliwości w orzecznictwie sądów administracyjnych. Przykładem może być chociażby wyrok WSA we Wrocławiu, w którym chodziło o udostępnienie informacji dotyczącej dotacji otrzymanej od Ministra Kultury i Dziedzictwa Narodowego na wykonywanie prac konserwatorskich ${ }^{25}$.

Naczelny Sąd Administracyjny podkreślił również, że „w skardze kasacyjnej nie podniesiono zarzutu błędnej kwalifikacji treści wniosku z dnia 15 maja 2018 r. jako dotyczącego w całości bądź w części kategorii informacji publicznej w rozumieniu art. 1 ust. 1 u.d.i.p. w związku z art. 61 ust. 1 Konstytucji RP, co wyklucza dopuszczalność wypowiadania się w tej kwestii przez Naczelny Sąd Administracyjny”. Należy w związku z tym zauważyć, że wyrok NSA nie dotyczy zakresu informacji, które miał udostępnić proboszcz, ale stwierdzenia, iż w związku z realizacją zadania publicznego ciąży na nim taki obowiązek. NSA nie przesądza więc tego, czy zarząd cmentarza wyznaniowego ma przekazać wnioskodawcy pełne dane, o które ten wnioskuje. Należy podkreślić, że Kościół Katolicki jest podmiotem, który swoje relacje z państwem opiera na ściśle określonych zasadach. Jedną z nich jest reguła sformułowana w art. 25 ust. 3 Konstytucji RP, w myśl której „stosunki między państwem a kościołami i innymi związkami wyznaniowymi są kształtowane na zasadach poszanowania ich autonomii oraz wzajemnej niezależności

25 Wyrok Wojewódzkiego Sądu Administracyjnego we Wrocławiu z dnia 9 sierpnia 2017 r., IV SAB/Wr 72/17. 
każdego w swoim zakresie, jak również współdziałania dla dobra człowieka i dobra wspólnego". Podobną treść ma również art. 1 Konkordatu z 1993 r. Z normy tej wyłaniają się dwa zasadnicze elementy. Po pierwsze, Kościół zachowuje autonomię i niezależność w zakresie regulowania spraw wewnętrznych, co daje mu możliwość kierowania się ustanowionymi przez siebie normami wewnętrznymi, również tymi odnoszącymi się do cmentarzy. Po drugie Kościół i państwo działają dla dobra jednostki i dobra wspólnego, co jednakże nie oznacza, że podczas wspólnych przedsięwzięć tracą swoją autonomię. Kwestia prowadzenia cmentarzy wyznaniowych jest doskonałym przykładem współdziałania dla dobra wspólnego, gdy umożliwia się pochowanie osób nienależących do danej wspólnoty, w imię szacunku dla doczesnych szczątków zmarłych.

W rozpatrywanej sprawie należy wyraźnie oddzielić kwestię pochówku osób należących do Kościoła Katolickiego od pogrzebu pozostałych osób. W odniesieniu do pierwszej grupy Kościół zachowuje autonomię rządzenia się własnym prawem i nie ma obowiązku udzielania informacji publicznej o szczegółach związanych z ich pogrzebem. W przypadku podmiotów należących do drugiej grupy taki obowiązek powstaje.

\section{WNIOSKI}

$\mathrm{Na}$ podstawie analizy wyroku Naczelnego Sądu Administracyjnego z dnia 4 grudnia 2020 r. (I OSK 125/19) można sformułować następujące uwagi:

1. Należy zgodzić się ze stanowiskiem NSA, który zauważa, że prowadzenie cmentarza wyznaniowego nie jest zadaniem publicznym obciążającym parafię, natomiast w kategorii tej mieści się obowiązek umożliwienia godnego pochówku niezależnie od tego, czy osoba zmarła należała do Kościoła Katolickiego.

2. Na podstawie analizy obowiązujących przepisów i stanowiska judykatury NSA słusznie uznał, że proboszcz w zakresie pełnionych funkcji może być zobowiązany do udostępnienia informacji publicznej.

3. Za prawidłową należy uznać również interpretację przepisów dotyczących rozdzielenia obowiązków w zakresie prowadzenia cmentarzy pomiędzy gminy i kościelne osoby prawne. 
4. Należy pozytywnie odnieść się do stanowiska NSA w kwestii doręczenia wniosku o udostępnienie danych osobowych za pomocą poczty elektronicznej. NSA poleca bowiem przyjąć domniemanie, zgodnie z którym, jeżeli wiadomość została prawidłowo nadana na oficjalny adres e-mail organu, to znaczy, że dotarła ona do adresata. Odmienne zapatrywanie sprawiałoby bowiem, że w praktyce prawo do wnioskowania o informację publiczną za pomocą poczty elektronicznej byłoby iluzoryczne, a jego skuteczność zależna byłaby od arbitralnej woli organu. Wynika to z braku sformalizowania procedury dostępu do informacji publicznej, w której powszechnie dopuszcza się możliwość składania takich wniosków.

\section{BIBLIOGRAFIA}

Aleksandrowicz, Tomasz. 2008. Ustawa o dostępie do informacji publicznej. Komentarz, wyd. 4. Warszawa: LexisNexis.

Dobosz, Piotr. 2017. „Wartości leżące u podstaw prawa cmentarnego”. W: Aksjologia prawa administracyjnego, T. 2, red. Jan Zimmermann. Warszawa: Wolters Kluwer.

Dziobek-Romański, Jacek. 1999. „Cmentarze - zarys regulacji historycznych, prawnych i kanonicznych". Rocznik Historyczno-Archiwalny 13: 3-33.

Hodor, Katarzyna. 2012. „Założenia cmentarne w krajobrazach Krakowa”. Czasopismo Techniczne 7: 279-286.

Kamińska, Irena, Mirosława Rozbicka-Ostrowska. 2016. Ustawa o dostępie do informacji publicznej. Komentarz, wyd. 3. Warszawa: Wolters Kluwer.

Marczak, Paulina. 2015. „Poszanowanie godności osoby zmarłej a działalność funeralna - zagadnienia wybrane". W: Non omnis moriar. Osobiste i majątkowe aspekty prawne śmierci człowieka. Zagadnienia wybrane, red. Daniel Karkut, Jacek Mazurkiewicz, Jacek Gołaczyński, Jarosław Trułkowski. Wrocław: Oficyna Prawnicza. 